\title{
Evaluation of the in vitro Anti-inflammatory Activity of Nerium oleander L. Flower Extracts and Activity-Guided Isolation of the Active Constituents
}

\author{
İrem Atay Balkan ${ }^{\oplus 1}$ *, Ahmet C. Gören ${ }^{\oplus 2}$, Hasan Kırmızıbekmez ${ }^{\oplus 3}$ and \\ Erdem Yeşilada ${ }^{\oplus 3}$
}

\author{
${ }^{I}$ Istanbul Medipol University, School of Pharmacy, Department of Pharmacognosy, 34810, Beykoz, \\ Istanbul, Türkiye \\ ${ }^{2}$ TUBITAK National Metrology Institute, Chemistry Group Laboratories, 41470, Gebze, Kocaeli, \\ Türkiye \\ ${ }^{3}$ Yeditepe University, Faculty of Pharmacy, Department of Pharmacognosy, 34755, Ataşehir, Istanbul, \\ Türkiye \\ (Received May 31, 2017; Revised August 11, 2017; Accepted August 24, 2017)
}

\begin{abstract}
The in vitro anti-inflammatory activity profile of the Nerium oleander flower EtOH extract/its subextracts (n-hexane, $\mathrm{CH}_{2} \mathrm{Cl}_{2}$, EtOAc, remaining $\mathrm{H}_{2} \mathrm{O}$ ) were evaluated on LPS induced Raw 264.7 macrophages. The effects of the crude EtOH extract and its subextracts on nitric oxide (NO) production and cell viability were determined. The most active subextract was determined to be the EtOAc subextract without exerting any toxicity towards Raw 264.7 macrophages. This subextract significantly inhibited NO production of Raw 264.7 macrophages after LPS induction $(62.56 \pm 1.91 \%$ at $200 \mu \mathrm{g} / \mathrm{mL}$ concentration). The levels of iNOS were reduced up to $67.50 \%$. Moreover, this subextract slightly reduced the phosphorylation levels of MAP kinases (p-ERK, p-JNK, p-38). The highest inhibition was observed for ERK phosphorylation, which was inhibited by $20.53 \%$ at $200 \mu \mathrm{g} / \mathrm{mL}$ concentration. Through activity-guided fractionation procedures, kaempferol, kaempferol 3-O- $\beta$-glucopyranoside and chlorogenic acid were isolated as the main active components. The structures of the active compounds were determined by 2D-NMR techniques and HRMS analysis. All compounds significantly inhibited NO productions. Results of the present study supported the traditional use of $N$. oleander flowers to treat inflammatory complaints.
\end{abstract}

Keywords: Nerium oleander; nitric oxide; mitogen activated protein kinases; kaempferol; kaempferol 3-O- $\beta$ glucopyranoside; chlorogenic acid. C 2018 ACG Publications. All rights reserved.

\section{Introduction}

Inflammation is a beneficial defense mechanism against various stress factors. However, chronic inflammation contributes crucially to the pathogenesis of many diseases including inflammatory bowel diseases, asthma, arthiritis as well as neurodegenerative diseases (e.g. Alzheimer's disease, multiple sclerosis) [1-6]. Such disorders are very common and constitute the main health problems of the worldwide society [7-10]. The complexity of the inflammatory reaction augments by the involvement of various pathways. These pathways include mediators like nitric oxide (NO), prostaglandins, leukotriens, platelet-activating factor, cytokines (IL-1, IL-6, TNF $\alpha$ ) and various

\footnotetext{
*Corresponding author: E-Mail: irematay@yahoo.com; Phone: +90 5358591938 Fax: +90 02125317555
} 
enzymes including lipoxygenases, inducible nitric oxide synthase (iNOS), cyclooxygenases (COX-1 and COX-2), and phospholipases [11-13]. Among the mediators, NO which is primarily an essential molecule for physiological functions of the body, was found to be associated with inflammation, sepsis and carcinogenesis at higher concentrations [14]. In order to evaluate the activity of drug candidates against inflammation, inhibition of NO production through reduced levels of iNOS was reported to be an important measure [15].

The mitogen activated protein (MAP) kinases are classified among the family of serine/threonine protein kinases [16, 17]. Three major groups of MAP kinases (ERK, JNK and p38) regulate the synthesis of many inflammatory mediators at the level of translation and transcription [6, 18]. It has been shown that MAP kinases (ERK, JNK and p38) regulate the production of LPS induced iNOS. Moreover, MAP kinases are found to be essential for COX-2 gene expression [19-21]. In addition, MAP kinases regulate the expressions of inflammatory mediators such as TNF $\alpha$, IL- $1 \beta$ and IL-6 [6].

$N$. oleander L. (Apocynaceae) or oleander is an evergreen ornamental shrub mainly distributed in the Mediterranean region [22]. Cardenolides, triterpenes, phytosterols, pregnanes and flavonoids were isolated from the leaves and steroidal glycosides were isolated from the roots of the plant [2334]. Various pharmacological activities have been reported for the leaves and roots of N.oleander such as cytotoxic, anticancer, anti-inflammatory, antibacterial, antioxidant, skin degenerative and central nervous system stimulant activities [27, 35-37].

Almost all the chemical and pharmacological investigations have been carried out so far focused particularly on the leaves of oleander, while its flowers remained to be unexplored, except a number of neuroprotective, hepatoprotective and antioxidant studies [38-44]. In Turkish folk medicine, oleander flowers are soaked in olive oil or alcohol and the macerate is applied topically to the aching extremities against rheumatic pain as a home remedy [45]. In our previous study, the ethanol (EtOH) extract of the flowers was shown to exert significant in vivo anti-inflammatory activity [46]. The present study aims to elucidate the activity mechanism and to isolate potential antiinflammatory metabolites through the in vitro activity-guided fractionation techniques. For that purpose, effects of the crude EtOH extract and the subextracts [ $n$-hexane, dichloromethane $\left(\mathrm{CH}_{2} \mathrm{Cl}_{2}\right)$, ethyl acetate (EtOAc) and remaining water $\left(\mathrm{R}-\mathrm{H}_{2} \mathrm{O}\right)$ ] were evaluated on LPS-induced NO production of Raw 264.7 cells. The EtOAc subextract which was the most potent subextract was further evaluated for its effects on iNOS and COX-2 protein levels. The effects on the phosphorylation levels of MAP kinases (ERK1/2, JNK and p38 kinases) were also targeted.

\section{Materials and Methods}

\subsection{General}

The column chromatography (CC) was achieved by using Sephadex LH-20 (Lipophilic Sephadex, 25-100 $\mu \mathrm{m}$, Sigma-Aldrich, USA), and Polyamide (Sigma-Aldrich, USA) as stationary phases. Kieselgel 60 F254 (Merck) precoated plates were used for thin layer chromatography. Lipopolysachharides (LPS), dimethylsulfoxide (DMSO), HRP-conjugated goat anti-mouse and antirabbit IgG and Griess reagent were purchased from Sigma-Aldrich (St. Louis, MO). Fetal bovine serum (FBS), Dulbecco's modified Eagle's medium (DMEM), penicillin-streptomycine was obtained from Invitrogen/Gibco (Grans Island, NY, USA). Antibodies for phospho-ERK1/2, ERK, phosphop38, p38, phospho-JNK, JNK were purchased from Cell Signaling Technology (Beverly, MA, USA). Antibodies for iNOS, COX-2 and $\beta$-actin were purchased from Santa Cruz (CA, USA). ECL reagent obtained from Amersham (Buckhinghamshire, UK). WST-1 reagent was from Roch Applied Science (Mannheim, Germany).

\subsection{Cells and Cell Culture}

The Raw 264.7 macrophages (ATCC TIB-71) were grown in DMEM which was supplemented with $10 \% \mathrm{FBS}, 4 \mathrm{mM}$ L-glutamin, $100 \mathrm{IU} / \mathrm{mL}$ penicillin and $100 \mu \mathrm{g} / \mathrm{mL}$ streptomycin at $37{ }^{\circ} \mathrm{C}$ in a humidified atmosphere containing $5 \% \mathrm{CO}_{2}$. 


\subsection{WST-1 Assay for Cell Viability}

Extract/subextracts/fractions or compounds were evaluated for their non-toxic concentrations by WST-1 assay kit (Roche Applied Sciences) in agreement with the manufacturer's instructions. Metabolically active cells reduces WST-1 which is a tetrazolium-based salt dye, to a formazan salt. The result can be directly quantified by spectrophotometric measurements. Raw 264.7 cells (22.500 cells/well) in 10\% FBS-DMEM were seeded into 96-well plates and various concentrations of samples were added to the wells with or without $1 \mu \mathrm{g} / \mathrm{mL}$ LPS. After $24 \mathrm{hrs}$ incubation at $37{ }^{\circ} \mathrm{C}$, the supernatant was removed, WST-1 was directly added to the wells to a final concentration of $5 \%(\mathrm{v} / \mathrm{v})$. After an additional 60 minutes of incubation at $37^{\circ} \mathrm{C}$ the absorbance was read between $420-480 \mathrm{~nm}$ $(\lambda \max 450 \mathrm{~nm})$. DMSO was used to dissolve all test samples. The samples were then diluted with DMEM to the convenient concentrations. The DMSO concentrations in the culture medium did not exceed $0.1 \%(\mathrm{v} / \mathrm{v})$.

\subsection{Griess Assay}

Raw 264.7 cells ( 22.500 cells/well) in 10\% FBS-DMEM were seeded into 96-well plates. The extract/subextracts/fractions were added to cells and incubated for one $\mathrm{hr}$, and then induced with 1 $\mu \mathrm{g} / \mathrm{mL}$ LPS. After that the plates were incubated for additional $24 \mathrm{hr}$ at $37^{\circ} \mathrm{C}$, the nitrite accumulated in the medium was measured by Griess Assay. The cell culture medium $(50 \mu \mathrm{L})$ was mixed with 50 $\mu \mathrm{L}$ of $1 \%(\mathrm{w} / \mathrm{v})$ sulfanilamide prepared $5 \%(\mathrm{v} / \mathrm{v})$ phosphoric acid. The reaction was incubated for 10 mins and then $50 \mu \mathrm{L}$ of $0.1 \%$ (w/v) naphtylethylenediamine- $\mathrm{HCl}$ (Promega) was added. The mixture was incubated for another 10 mins at room temperature. The absorbance was read at $550 \mathrm{~nm}$ using a microplate reader. The nitrite amounts in the test samples were calculated from the $\mathrm{NaNO}_{2}$ serial dilution standard curve.

\subsection{Western Blotting}

Cells were washed once with ice-cold PBS and the cellular proteins were extracted by RIPA lysis buffer composed of $1 \mathrm{x}$ TBS, $1 \%$ Nonidet P-40, $0.5 \%$ sodium deoxycholate and $0.1 \%$ SDS with $0.004 \%$ sodium azide (Santa Cruz). The RIPA buffer was supplemented with $1 \mathrm{mM}$ phenylmethylsulfonyl fluoride $1 \mathrm{mM} \mathrm{Na}$ ortho-vanadate, $1 \%$ protease inhibitor cocktail (Sigma). The protein concentrations were calculated by using Lowry assay. Forty micrograms of cellular proteins were separated by $8 \%$ or $\% 10$ SDS-polyacrylamide gel electrophoresis. After that, the proteins were electroblotted onto a nitrocellulose membrane. The membranes were incubated with specific primary antibodies overnight at $4{ }^{\circ} \mathrm{C}$ with $5 \%$ skim milk as blocking solution. Blots were washed with Tween 20/Tris-buffered saline (TBST) for four times. Then the membranes were incubated for $2 \mathrm{hr}$ at room temperature with a 1:1000 dilution of secondary antibodies. Eventually, blots were washed three times with TBST, and then visualised by ECL reagent (Amersham Life Science).

\subsection{Plant Material}

The flowers of $N$. oleander were collected from Kayışdağı-İstanbul (Turkey) in June, 2010. The identification of the plant material was achieved by Prof. Dr. Erdem Yesilada (one of the authors). A voucher specimen is deposited at the Herbarium of Yeditepe University (YEF 10009).

\subsection{Extraction and Isolation}

The fresh flowers of $N$. oleander $(2.5 \mathrm{~kg})$ were macerated with EtOH $(700 \mathrm{~mL})$ at room temperature for 50 days. The macerate was filtered through filter paper. The organic phase was evaporated to dryness under reduced pressure. As a result, crude EtOH extract was obtained (105.71 g, yield: 4.24\%). EtOH extract was dispersed in $100 \mathrm{~mL}$ of $\mathrm{MeOH}$ in $\mathrm{H}_{2} \mathrm{O}(90 \%$, v/v) and partitioned 
against $n$-hexane $(4 \times 200 \mathrm{~mL})$. The $n$-hexane phases were combined. Subsequently, $n$-hexane was evaporated under reduced pressure in order to obtain $n$-hexane subextract ( $3 \mathrm{~g}$, yield: $6 \%$ ). After removing the $\mathrm{MeOH}$ from the remaining extract, the volume of the solution was adjusted to $100 \mathrm{~mL}$ with distilled $\mathrm{H}_{2} \mathrm{O}$ and partition continued with $\mathrm{CH}_{2} \mathrm{Cl}_{2}(4 \times 200 \mathrm{~mL})$ and then EtOAc $(4 \times 200 \mathrm{~mL})$, respectively. Each organic phase was evaporated to dryness under reduced pressure to yield $\mathrm{CH}_{2} \mathrm{Cl}_{2}(2$ g, yield: $4 \%$ ), EtOAc (1.1 g, yield: 2,2\%) subextracts while remaining- $\mathrm{H}_{2} \mathrm{O}$ subextract was lyophilized (30.5 g, yield: $60,1 \%)$.

The EtOAc subextract ( $1.3 \mathrm{~g})$ was submitted to a polyamide $(20 \mathrm{~g})$ column eluting with $\mathrm{H}_{2} \mathrm{O}$ $(200 \mathrm{~mL})$ and mixtures of $\mathrm{MeOH}$ in $\mathrm{H}_{2} \mathrm{O}(10-100 \%$ in steps of $10 \%$, each $100 \mathrm{~mL})$ in order to obtain four fractions, Fr. A-D. Fr. B (90 mg) was applied to a Sephadex $(20 \mathrm{~g})$ column using $\mathrm{MeOH}$ and chlorogenic acid (CA, $4 \mathrm{mg}$ ) was obtained. Fr. C $(50 \mathrm{mg})$ was further subjected to a $\mathrm{SiO}_{2}(8 \mathrm{~g})$ column using mixtures of $\mathrm{CH}_{2} \mathrm{Cl}_{2}-\mathrm{MeOH}(90: 10,85: 15,70: 30,60: 40$ and 50:50; each $100 \mathrm{~mL})$ to yield kaempferol 3-O- $\beta$-glucopyranoside $(\mathrm{KG}, 6 \mathrm{mg})$. The Fr. D $(51 \mathrm{mg})$ was applied to a Sephadex $(20 \mathrm{~g})$ column using $\mathrm{CH}_{2} \mathrm{Cl}_{2}-\mathrm{MeOH}$ (1:1) mixture to yield kaempferol (KF, $\left.22 \mathrm{mg}\right)$. The chemical structures of these compounds were given in Figure 1.

\subsection{Structure Elucidation of the Compounds}

The elucidation of the structures of the pure compunds were achieved by Nuclear Magnetic Resonance $\left({ }^{1} \mathrm{H}\right.$ and ${ }^{13} \mathrm{C}$ NMR) and Mass Spectral (MS) techniques. NMR spectra were recorded on a Varian Mercury-Mx spectrometer (USA) at $600 \mathrm{MHz}$ for ${ }^{1} \mathrm{H}$ NMR and at $150 \mathrm{MHz}$ for ${ }^{13} \mathrm{C}$ NMR, with $\mathrm{CD}_{3} \mathrm{OD}$ as solvents. UV and IR spectra were recorded on an HP Aglient 8453 (USA) UV and PerkinElmer-2000 FT-IR spectrometers respectively (USA).

\subsection{Statistical Analysis}

The data were recorded as mean \pm standard error of the mean (SEM) of triplicate experiments. The data were analyzed by PASW Statistics. The significance of the difference between means were determined by Mann Whitney $U$ test and $p$-values less than 0.05 were considered statistically significant.
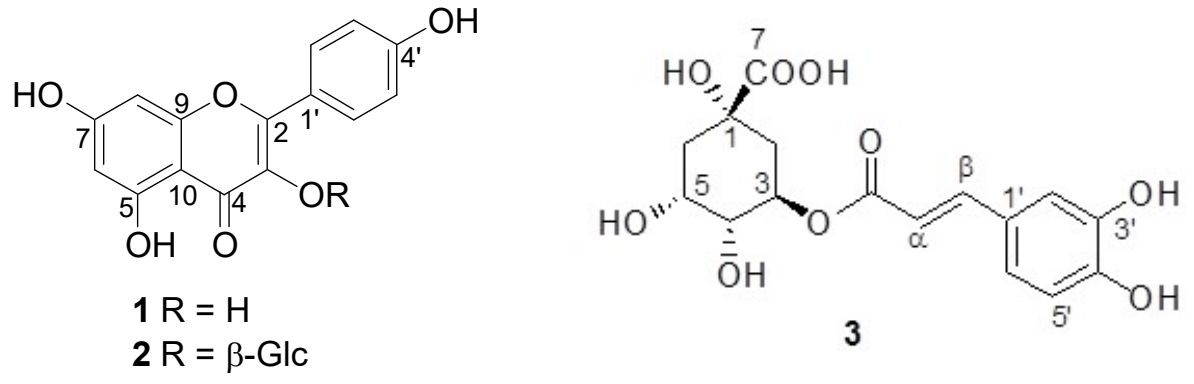

Figure 1. Chemical structures of the active compounds (1-3).

\section{Results and Discussion}

\subsection{Activity-guided Fractionation of N. oleander EtOH Extract}

\subsubsection{Effects of EtOH Extract and Subextracts on Cell Viability}

Non-toxic concentrations of the extract/subextracts on Raw 264.7 macrophage cells were determined by WST-1 assay. When EtOH extract was applied at $100 \mu \mathrm{g} / \mathrm{mL}$, the viability of Raw 264.7 macrophage cells was $85.00 \pm 3.15 \%$ comparing to only media treated control group (Figure 2). The $n$-hexane, EtOAc and $\mathrm{R}-\mathrm{H}_{2} \mathrm{O}$ subextracts were applied at $100 \mu \mathrm{g} / \mathrm{mL}$ concentrations and the 
viability of Raw 264.7 macrophage cells were determined to be $109.67 \pm 2.48 \%, 103.75 \pm 3.54 \%$, and $77.81 \pm 2.76$, respectively. The $\mathrm{CH}_{2} \mathrm{Cl}_{2}$ subextract was applied at $50 \mu \mathrm{g} / \mathrm{mL}$ and the cell viability was $89.29 \pm 2.08$.

\subsubsection{Effects of EtOH Extract and Subextracts on NO Production}

The NO levels of LPS-induced cells were significanly increased (14.64 $\pm 0.32 \mu \mathrm{M})$ comparing to the untreated cells $(0.14 \pm 0.14 \mu \mathrm{M})$. The EtOH extract of the flowers slightly decreased the NO levels $(12.79 \pm 0.45 \mu \mathrm{M})$ at $100 \mu \mathrm{g} / \mathrm{mL}$ concentration. However, NO production was significantly inhibited by treatment of Raw 264.7 macrophage cells with EtOAc $(7.68 \pm 0.55 \mu \mathrm{M})$ and $n$-hexane $(8.98 \pm 0.53 \mu \mathrm{M})$ subextracts at $100 \mu \mathrm{g} / \mathrm{mL}$ concentrations. The $\mathrm{CH}_{2} \mathrm{Cl}_{2}$ subextract was applied to cells at $50 \mu \mathrm{g} / \mathrm{mL}$ concentration and significantly decreased $(8.40 \pm 0.63 \mu \mathrm{M})$ the NO production. As shown in Figure 2, the remaning aqueous extract did not decrease but slightly increased NO production of the cells $(16.33 \pm 3.83 \mu \mathrm{M})$. Consequently, the most active subextract was found to be EtOAc subextract which inhibited $46.58 \%$ of NO production without showing toxicity towards Raw 264.7 macrophage cells at $100 \mu \mathrm{g} / \mathrm{mL}$ concentration. For that reason, we selected this subextract for further in vitro antiinflammatory activity evaluation and activity guided fractionation procedures.

(A)

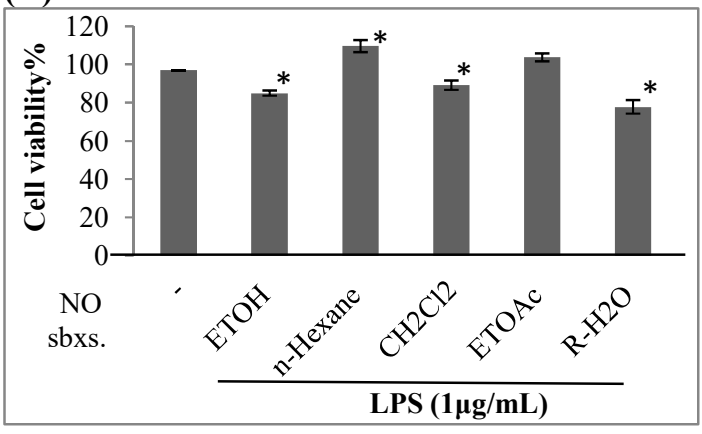

(B)

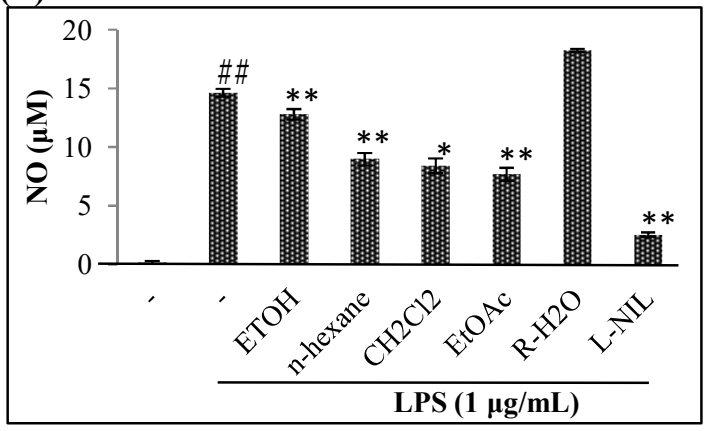

Figure 2. The effects of EtOH $(100 \mu \mathrm{g} / \mathrm{mL})$ extract and its subextracts $[n$-hexane $(100 \mu \mathrm{g} / \mathrm{mL})$, $\mathrm{CH}_{2} \mathrm{Cl}_{2}(50 \mu \mathrm{g} / \mathrm{mL})$, EtOAc $\left.(100 \mu \mathrm{g} / \mathrm{mL}), \mathrm{R}^{-} \mathrm{H}_{2} \mathrm{O}(100 \mu \mathrm{g} / \mathrm{mL})\right]$ on the viability (A) and NO productions (B) of LPS induced Raw 264.7 cells. Cells were treated with the indicated concentrations of the extracts with LPS $(1 \mu \mathrm{g} / \mathrm{mL})$ for $24 \mathrm{hrs}$. L-NIL was applied at $10 \mu \mathrm{M}$. Error bars represent the mean \pm SEM for three experiments. Values of $* p \leq 0.05, * * p \leq 0.01$ and $* * * p \leq 0.001$ were considered statistically significant.

\subsection{In vitro Anti-inflammatory Effect of N. oleander EtOAc Subextract}

\subsubsection{Effects of EtOAc Subextract on Cell Viability and NO Productions}

Raw 264.7 macrophage cells were treated with the EtOAc subextract at 25, 50, 100 and 200 $\mu \mathrm{g} / \mathrm{mL}$ concentrations with or without LPS $(1 \mu \mathrm{g} / \mathrm{mL})$ for $24 \mathrm{hrs}$. The cell viability was not significantly affected (Figure 3). When EtOAc subextract was applied to cells at 50, 100 and 200 $\mu \mathrm{g} / \mathrm{mL}$ concentrations, NO production of the cells were inhibited by $11.23 \pm 6.62 \%, 47.58 \pm 5.31 \%$ and $62.56 \pm 1.91 \%$, respectively, while at a lower concentration $(25 \mu \mathrm{g} / \mathrm{mL})$ the inhibition rate was not significant. 
(A)

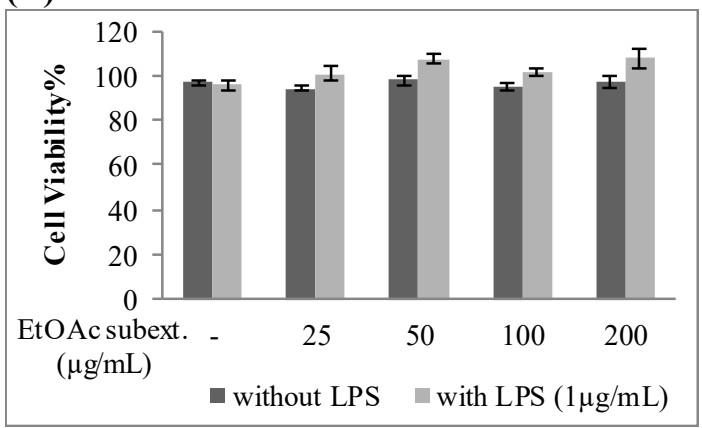

(B)

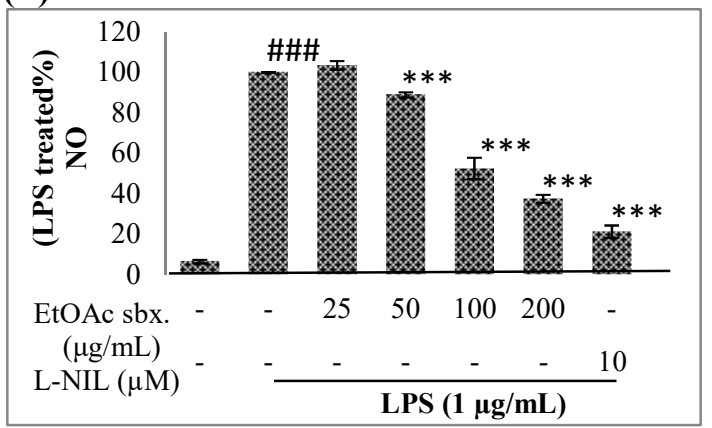

Figure 3. The effects of $N$. oleander EtOAc extract on cell viability (A) and NO production (B) of LPS induced Raw 264.7 cells. Raw 264.7 macrophage cells were treated with the indicated concentrations of $N$. oleander EtOAc extract with or without LPS for 24 hours. Cell viablity was determined using WST-1 reagent (A). Raw 264.7 cells were treated with the indicated concentrations of $N$. oleander EtOAc extract and LPS $(1 \mu \mathrm{g} / \mathrm{mL})$ for $24 \mathrm{hrs}$. Media were collected and NO concentrations were determined by Griess Assay (B). Error bars represent the mean \pm SEM for three experiments. Values of $* \mathrm{p} \leq 0.05, * * \mathrm{p} \leq 0.01$ and $* * * \mathrm{p} \leq 0.001$ were considered statistically significant.

(A)
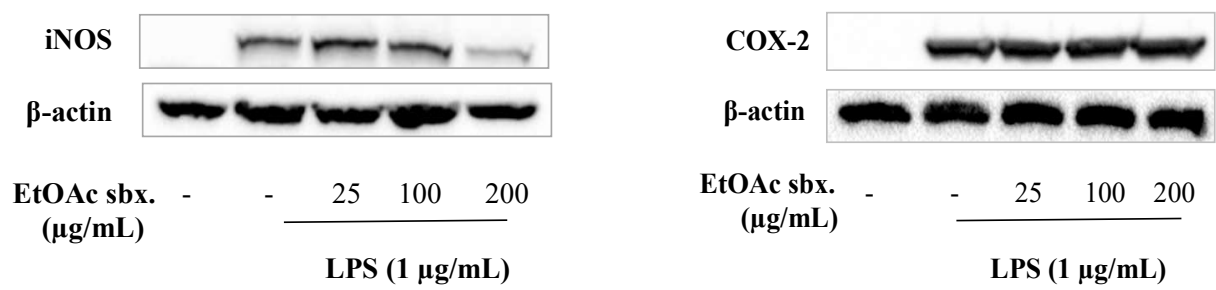

(B)
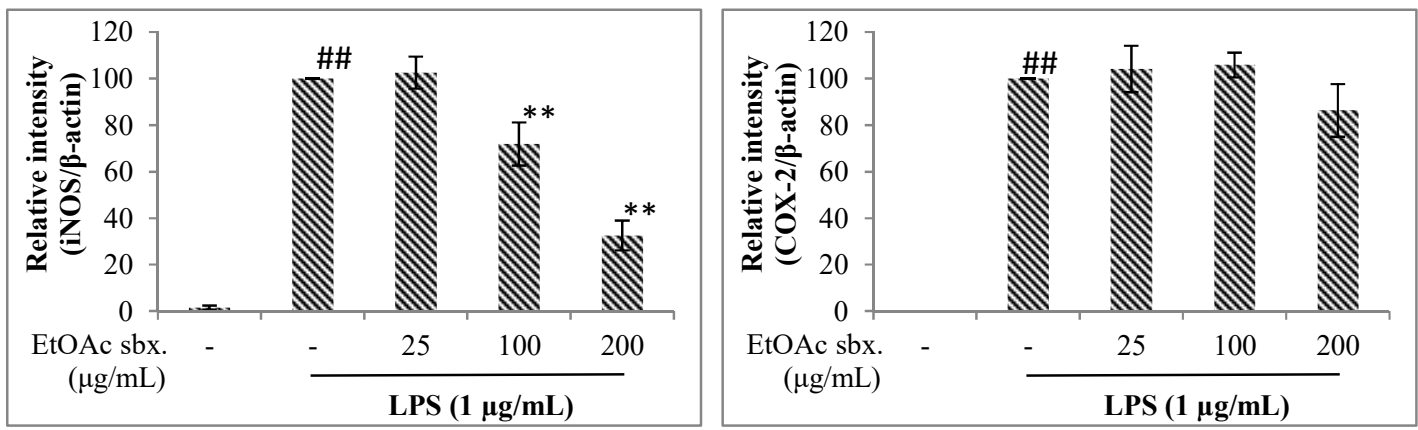

Figure 4. Effects of $N$. oleander EtOAc subextract on iNOS and COX-2 protein levels of LPS induced Raw 264.7 macrophages. Raw 264.7 macrophage cells were pretreated for $1 \mathrm{hr}$ with the indicated concentrations of $N$. oleander EtOAc subextract and then induced with LPS for a total of $24 \mathrm{hrs}$. After that cells were lysed and iNOS and COX-2 proteins were detected with Western Blot using specific antibodies. Equal loading was verified by $\beta$-actin antibody. A representative image of three independent experiments is shown (A). Relative band intensities measured by Image J. (B). The data are means \pm SEM of three independent experiments. $* p \leq 0.05 * * p \leq 0.01 * * * p \leq 0.001$ compared to LPS treated group \# $p \leq 0.05 \# \# p \leq 0.01 \# \# \# p \leq 0.001$ compared to non-induced group. 


\subsubsection{Effects of EtOAc Subextract on iNOS and COX-2 Levels}

In order to determine whether inhibition of $\mathrm{NO}$ release by EtOAc subextract was associated with the reduced levels of iNOS, protein levels were determined by Western Blot. Raw 264.7 macrophages were pretreated with 25, 100 and $200 \mu \mathrm{g} / \mathrm{mL}$ of EtOAc subextract for one $\mathrm{hr}$ and then treated with LPS for $24 \mathrm{hrs}$. As shown in Figure 3, the EtOAC subextract significantly decreased iNOS levels in a concentration-dependent manner. The iNOS levels reduced by $34.10 \%$ and $67.50 \%$ at 100 and $200 \mu \mathrm{g} / \mathrm{mL}$ concentrations, respectively, comparing to only LPS-treated $(1 \mu \mathrm{g} / \mathrm{mL})$ control group. Consistent with the effects on NO production, no inhibition was observed with $25 \mu \mathrm{g} / \mathrm{mL}$ of EtOAc subextract. On the other hand, EtOAc subextract slightly decreased (13.69\%) COX-2 enzyme levels only at $200 \mu \mathrm{g} / \mathrm{mL}$ concentration (Figure 4).

\subsubsection{Effects of EtOAc Subextract on LPS-induced MAP Kinase Levels}

Effect of the EtOAc subextract on the phosphorylation levels of MAP kinases were also investigated in order to explain its activity mechanism. Raw 264.7 macrophages were pretreated with 100 and $200 \mu \mathrm{g} / \mathrm{mL}$ EtOAc subextract and then treated with $1 \mu \mathrm{g} / \mathrm{mL}$ LPS for $15 \mathrm{~min}$. Principally this stimulation would expected to increase ERK, JNK and p38 phosphorylations significantly (Figure 5). However, pretreatment of cells with EtOAc subextract slightly decreased the phosphorylation levels of MAP kinases. The highest inhibition was observed for ERK, which was $12.87 \%$ and $20.53 \%$ at 100 and $200 \mu \mathrm{g} / \mathrm{mL}$ concentrations, respectively. JNK phosphorylation was inhibited by $8.88 \%$ and $11.25 \%$ at the same concentrations. While the $\mathrm{p} 38$ phosphorylation was not affected by the increase in concentration ( $15.95 \%$ and $15.11 \%$ inhibitions at 100 and $200 \mu \mathrm{g} / \mathrm{mL}$ concentrations).
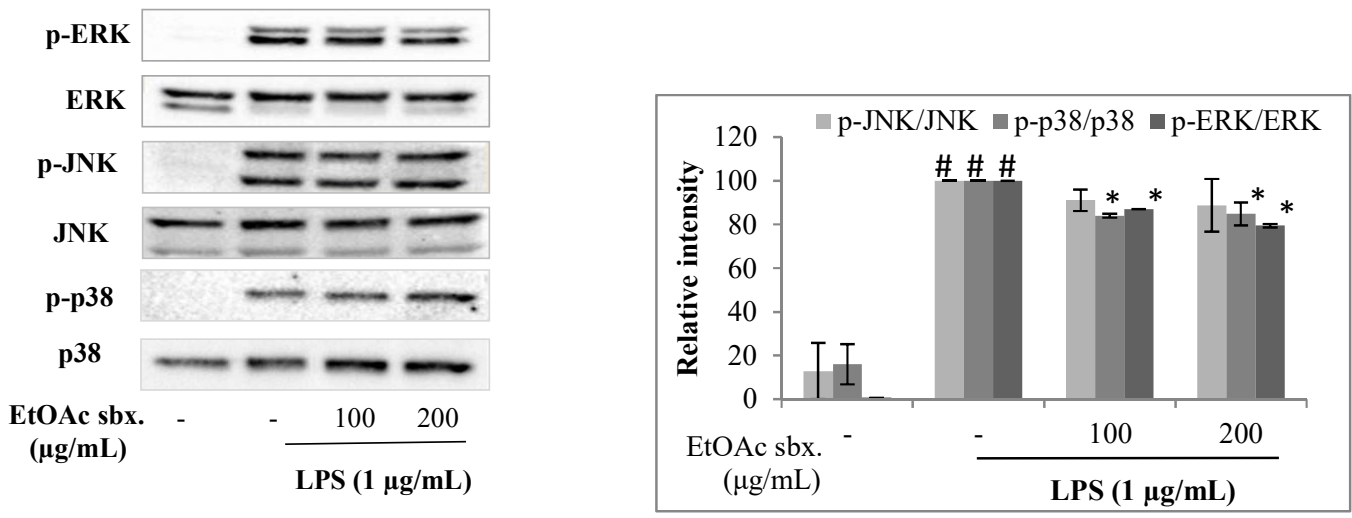

Figure 5. Effects of $N$. oleander EtOAc subextract on phosphorylation levels of MAP kinases on LPS induced Raw 264.7 macrophages. Raw 264.7 macrophage cells were pretreated for 2 hrs with the indicated concentrations of EtOAc subextract and then induced with LPS for 15 mins. Cells were lysed and MAP kinases (p-ERK, p-JNK, p-p38) proteins were detected with Western Blot using specific antibodies. Data was normalized to the corresponding total proteins (ERK, JNK, p38). A representative image of three independent experiments is shown (A). Relative band intensities measured by Image $\mathrm{J}(\mathrm{B})$. The data are means \pm SEM of three independent experiments. $* p \leq 0.05 * *$ $p \leq 0.01 * * * p \leq 0.001$ compared to LPS treated group \# $p \leq 0.05 \# \# p \leq 0.01 \# \# \# p \leq 0.001$ compared to non-induced group. 


\subsection{Activity-guided Fractionation of N. oleander EtOAc Subextract and Isolation of Its Active Components}

\subsubsection{Effects of Fractions on Cell Viability}

The EtOAc subextract was first fractionated by open column chromatography using polyamide as the stationary phase into four fractions: Fr. A, Fr. B, Fr. C, Fr. D. To determine the nontoxic concentrations, Fr. A, Fr. B and Fr. C were applied to cells at $100 \mu \mathrm{g} / \mathrm{mL}$ concentration and the cell viabilities were measured to be $95.99 \pm 2.61 \%, 83.29 \pm 1.08 \%, 90.64 \pm 3.37 \%$. Fr D was applied to cells at $50 \mu \mathrm{g} / \mathrm{mL}$ and the cell viablity was determined to be $100.30 \pm 0.12 \%$ (Figure 6).

\subsubsection{Effects of Fractions on NO Production}

As shown in Figure 6, NO levels of the LPS treated cells $(14,24 \pm 0,41 \mu \mathrm{M})$ were significantly increased comparing to untreated cells $(0,36 \pm 0,23 \mu \mathrm{M})$. The most active fractions were found to be $\mathrm{Fr}$ B $(2.83 \pm 0.36 \mu \mathrm{M})$ and Fr C $(6.94 \pm 0.22 \mu \mathrm{M})$. Fr D also moderately inhibited NO production of the cells $(8.57 \pm 0.71 \mu \mathrm{M})$. Fr A slightly inhibited NO production $(10.78 \pm 1.15)$ hence it was excluded from further studies. Consequently, through activity guided fractionation of the EtOAc subextract, kaempferol-3-O- $\beta$-D-glucoside $(\mathrm{KG})$ was isolated from Fr.B, chlorogenic acid (CA) and kaempferol (KF) were isolated from Fr. C and Fr. D, respectively. The structure elucidation of these molecules were summarized at Section 3.5.

(A)

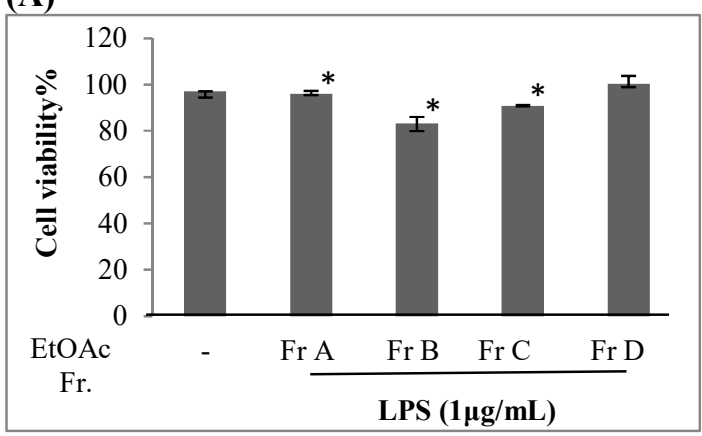

(B)

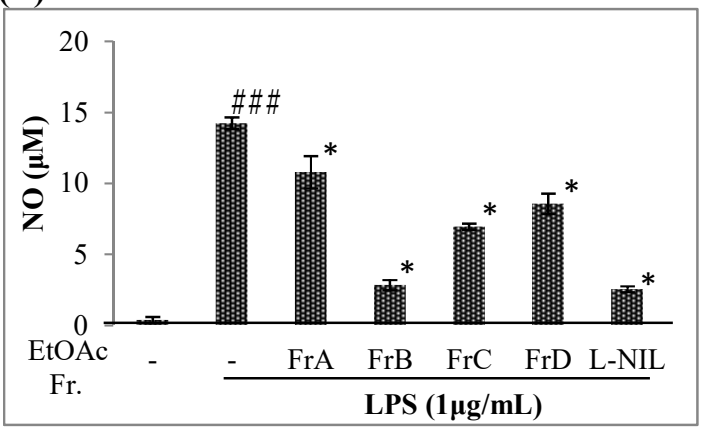

Figure 6. The effects of the fractions [Fr A $(100 \mu \mathrm{g} / \mathrm{mL})$, Fr B $(100 \mu \mathrm{g} / \mathrm{mL}), \operatorname{Fr} C(100 \mu \mathrm{g} / \mathrm{mL}), \operatorname{Fr} D$ $(100 \mu \mathrm{g} / \mathrm{mL})]$ of the EtOAc subextract on cell viability (A) and NO production (B) of LPS induced Raw 264.7 cells. Raw 264.7 cells were treated with the indicated concentrations of fractions with LPS for 24 hrs. Cell viablity was determined by using WST-1 reagent (A). Raw 264.7 cells were treated with the fractions and LPS $(1 \mu \mathrm{g} / \mathrm{mL})$ for $24 \mathrm{hrs}$. L-NIL was applied at $10 \mu \mathrm{M}$. Media were collected and NO concentrations were determined by Griess Assay (B). Error bars represent the mean \pm SEM for three experiments. Values of ${ }^{*} p \leq 0.05,{ }^{* *} p \leq 0.01$ and ${ }^{* * *} p \leq 0.001$ were considered statistically significant.

\subsection{Effects of Active Compounds on NO Production}

All compounds significantly reduced the levels of NO, but the most active compound was found to be KF. This molecule did not induce any significant decrease on the viability of Raw 264.7 macrophages up to $50 \mu \mathrm{g} / \mathrm{mL}$ concentration. KF inhibited NO production of the cells by $19.51 \%$, $65.10 \%, 86.19 \%$ at $12.5,25$ and $50 \mu \mathrm{g} / \mathrm{mL}$ concentrations. That effect was higher than that of L-NIL $(5 \mu \mathrm{M})$ which is a known NO inhibitor $(52.77 \%)$. The viability of Raw 264.7 macrophages was not significantly affected when CA and $\mathrm{KG}$ was applied at $12.5,25,50$ and $100 \mu \mathrm{g} / \mathrm{mL}$ concentrations. CA inhibited $33.74 \%, 35.01 \%, 38.12 \%, 55.96 \%$ of $\mathrm{NO}$ productions at these concentrations. KG inhibited $32.57 \%, 41.27$ and $46.40 \%$ of $\mathrm{NO}$ at $12.5,25$ and $50 \mu \mathrm{g} / \mathrm{mL}$ concentrations. The inhibitory effects of CA and KG were also found to be comparable to L-NIL (Figure 7). 
(A)

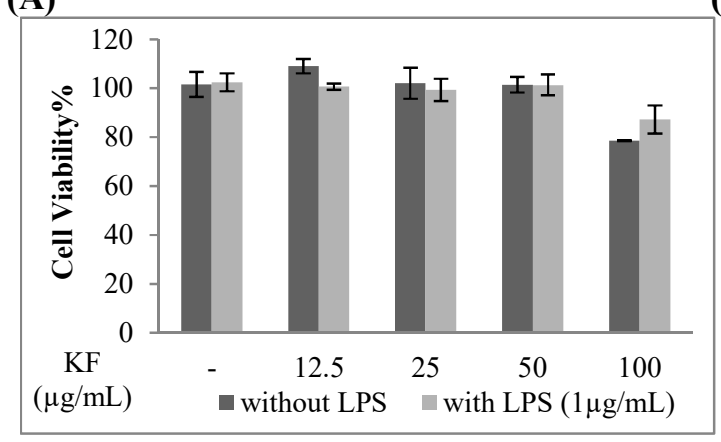

(B)

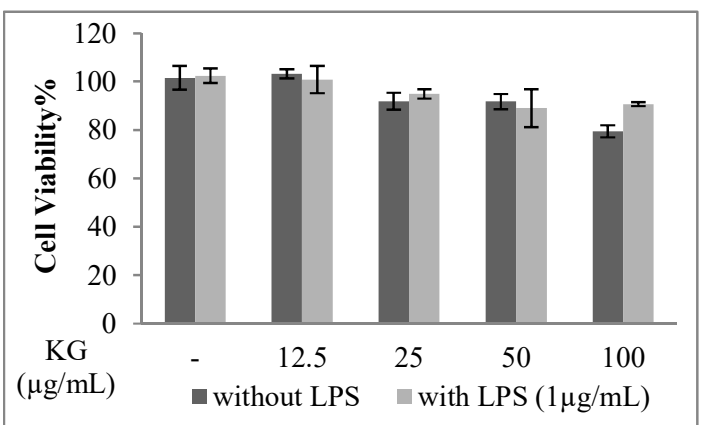

(C)

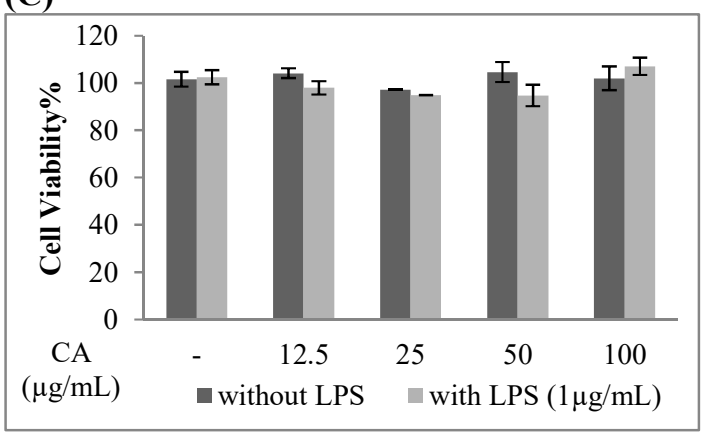

Figure 7. The effects of kaempferol (KF), kaempferol 3-O- $\beta$-glucopyranoside (KG) and chlorogenic acid (CA) on cell viability of Raw 264.7 cells. Raw 264.7 cells were treated with the indicated concentrations of KF (A), KG (B) and CA (C) with or without LPS for 24 hours. Cell viablity was determined by using WST-1 reagent. Error bars represent the mean \pm SEM for three experiments. Values of $* \leq 0.05, * * p \leq 0.01$ and ${ }^{* * *} p \leq 0.001$ were considered statistically significant.

\subsection{Structure Elucidation of the Active Components}

The structures of the isolates were elucidated on the basis of their NMR $\left({ }^{1} \mathrm{H}\right.$ - and $\left.{ }^{13} \mathrm{C}-\mathrm{NMR}\right)$ and HR-MS analysis and by comparison of their spectroscopic data with those published earlier.

Kaempferol (1): (KF) was obtained as a yellow amorphous powder; $\mathrm{C}_{15} \mathrm{H}_{10} \mathrm{O}_{6}$, UV $\left(\mathrm{CHCl}_{3}\right)$ $\lambda_{\max }: 268,369$, IR (KBr) $v_{\max } \mathrm{cm}^{-1}: 3349,1655,1605,1359,1283,1209,1180,1067$, HR-MS: $\mathrm{m} / z=$ 287.0538 (calculated: 287.0555$),{ }^{1} \mathrm{H}$ NMR $\left(600 \mathrm{MHz}, \mathrm{CD}_{3} \mathrm{OD}\right) \delta_{\mathrm{H}}: 8.08\left(d, J=8.6 \mathrm{~Hz}, \mathrm{H}-2^{\prime} / 6^{\prime}\right), 6.90$ $\left(d, J=8.6 \mathrm{~Hz}, \mathrm{H}-3^{\prime} / 5^{\prime}\right), 6.39(d, J=1.8, \mathrm{H}-8), 6.17(d, J=1.8, \mathrm{H}-6)$ and ${ }^{13} \mathrm{C}$ NMR $(150 \mathrm{MHz}$, $\left.\mathrm{CD}_{3} \mathrm{OD}\right) \delta_{\mathrm{C}}: 176.0(\mathrm{C}-4), 164.0(\mathrm{C}-7), 160.1(\mathrm{C}-5), 159.0\left(\mathrm{C}-4^{\prime}\right), 156.0$ (C-9), 153.5 (C-2), 135.0 (C3), $130.0\left(\mathrm{C}-2^{\prime} / 6^{\prime}\right), 122.0\left(\mathrm{C}-1^{\prime}\right), 114.0\left(\mathrm{C}-3^{\prime} / 5^{\prime}\right), 103.0$ (C-10), 98.0 (C-6), 93.0 (C-8). These data were confirmed by the previous data [47].

Kaempferol-3-O- $\beta$-glucopyranoside (2): (KG) was also obtained as a yellow amorphous powder; $\mathrm{C}_{21} \mathrm{H}_{20} \mathrm{O}_{11}$, UV (MeOH) $\lambda_{\max }: 266,354$, IR (KBr) $v_{\max } \mathrm{cm}^{-1}: 3365,1686,1594,1403,1265$, 1121, HR-ESI-MS: $m / z=471.0920[\mathrm{M}+\mathrm{Na}]^{+}$(calculated: 471.0903$),{ }^{1} \mathrm{H}$ NMR $\left(600 \mathrm{MHz}, \mathrm{CD}_{3} \mathrm{OD}\right)$ $\delta_{\mathrm{H}}: 8.05\left(d, J=8.8 \mathrm{~Hz}, \mathrm{H}-2^{\prime} / 6^{\prime}\right), 6.90\left(d, J=8.8 \mathrm{~Hz}, \mathrm{H}-3^{\prime} / 5^{\prime}\right), 6.36(d, J=2.0 \mathrm{~Hz}, \mathrm{H}-8), 6.17(d, J=$ $2.0 \mathrm{~Hz}, \mathrm{H}-6), 5.21\left(d, J=7.7 \mathrm{~Hz}, \mathrm{H}-1^{\prime \prime}\right), 3.67\left(d d, J=2.3,11.7 \mathrm{~Hz}, \mathrm{H}-6 \mathrm{a}^{\prime \prime}\right), 3.53(d d, J=5.3,11.7 \mathrm{~Hz}$, H-6b") $3.44\left(d d, J=7.7,8.8 \mathrm{~Hz}, \mathrm{H}-2^{\prime \prime}\right), 3.40\left(t, J=8.3 \mathrm{~Hz} \mathrm{H}-3^{\prime \prime}\right), 3.30\left(m, \mathrm{H}-4^{\prime \prime}\right), 3.19\left(m, \mathrm{H}-5^{\prime \prime}\right)$, and ${ }^{13} \mathrm{C}$ NMR $\left(150 \mathrm{MHz}, \mathrm{CDCl}_{3}\right) \delta_{\mathrm{C}}: 176.0(\mathrm{C}-4), 166.5$ (C-7), $162.0(\mathrm{C}-5), 160.3$ (C-4'), 157.2 (C-9), 153.5 (C-2), 133.0 (C-3), 130.3 (C-2'/6'), $120.4\left(\mathrm{C}-1^{\prime}\right), 114.0$ (C-3'/C-5'), 103.8 (C-10), 103.0 (C-1"), 98.0 (C-6), 93.0 (C-8), 77.5 (C-5"), 76.8 (C-3"), 74.5 (C-2"), 70.0 (C-4"), 60.8 (C-6"). These data was found to be in accordance with the previous published data [47].

Chlorogenic acid (3): (CA) was obtained as a yellow amorphous powder; $\mathrm{C}_{16} \mathrm{H}_{18} \mathrm{O}_{9}$, UV $(\mathrm{MeOH}) \lambda_{\max } \mathrm{nm}: 329$, IR (KBr) $v_{\max } \mathrm{cm}^{-1}: 3360,1660,1613,1510,1258,1177$, HR-ESI-MS: $m / z=$ 
$377.0981[\mathrm{M}+\mathrm{Na}]^{+}$, (calculated: 377.0849$),{ }^{1} \mathrm{H}$ NMR $\left(600 \mathrm{MHz}, \mathrm{CD}_{3} \mathrm{OD}\right) \delta_{\mathrm{H}}: 7.57(d, J=15.8 \mathrm{~Hz}, \mathrm{H}-$ $\beta), 7.05\left(d, J=2,3 \mathrm{~Hz}, \mathrm{H}-2^{\prime}\right), 6.96\left(d d, J=2.4,8.2 \mathrm{~Hz}, \mathrm{H}-6^{\prime}\right), 6.77\left(d, J=8.2 \mathrm{~Hz}, \mathrm{H}-5^{\prime}\right), 6.28$ ( $d, J=$ $15.8 \mathrm{~Hz}, \mathrm{H}-\alpha), 5.20$ ( $m, \mathrm{H}-3), 4.12$ (m, H-5), 3.70 (dd, H-4), 2.15 ( $m, \mathrm{H}-2 \mathrm{a}), 2.01$ (m, H-6a), 2.09 ( $m$, $\mathrm{H}-6 \mathrm{~b}), 1.95(\mathrm{~m}, \mathrm{H}-2 \mathrm{~b})$, and ${ }^{13} \mathrm{C}$ NMR $\left(150 \mathrm{MHz}, \mathrm{CD}_{3} \mathrm{OD}\right) \delta_{\mathrm{C}}: 180.0(\mathrm{C}-7), 168.0(\mathrm{C}=\mathrm{O}, c a f),$. (C-4'), 145.9 (C-3'), 145.9 (C- $\beta$ ), 126.5 (C-1'), 121.9 (C-6'), 115.0 (C-5'), $114.0\left(\mathrm{C}-2^{\prime}\right), 113.9$ (C- $\left.\alpha\right)$, 76.5 (C-1), 73.9 (C-4), 71.9 (C-3), 71.2 (C-5), 39.2 (C-6), 38.0 (C-2). These data was consistent with the literature [48].

(A)

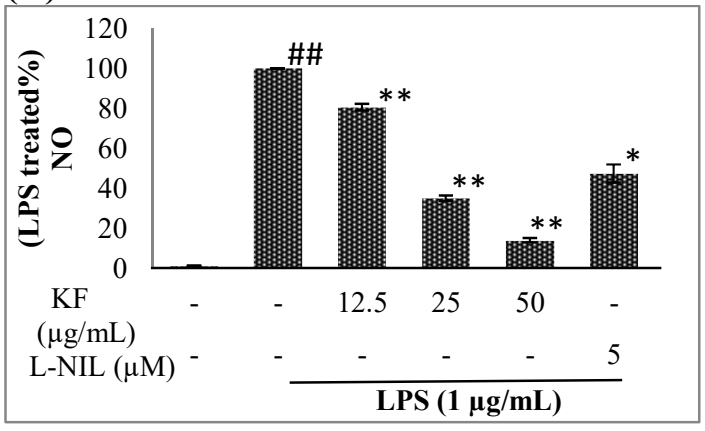

(B)

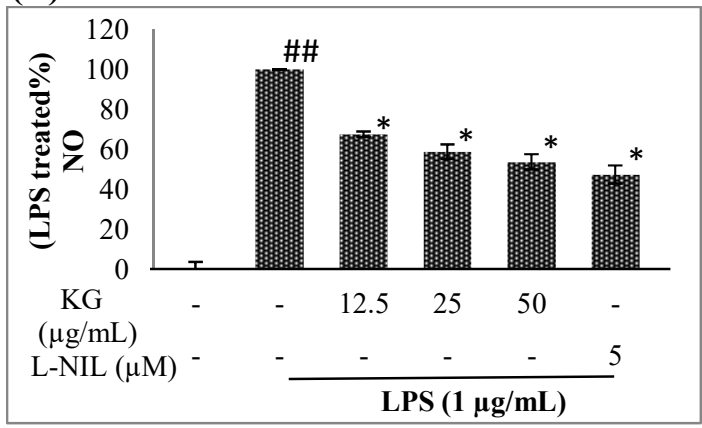

(C)

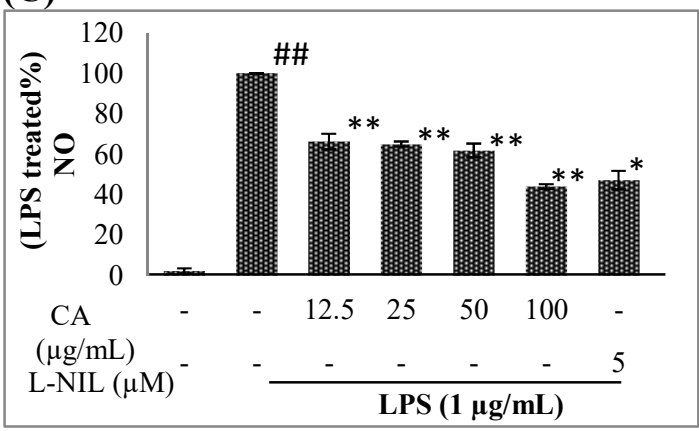

Figure 8. The effects of kaempferol (KF), kaempferol 3-O- $\beta$-glucopyranoside (KG) and chlorogenic acid (CA) on NO production (B) of LPS induced Raw 264.7 cells. Raw 264.7 cells were treated with the indicated concentrations of KF (A), KG (B) and CA (C) with LPS $(1 \mu \mathrm{g} / \mathrm{mL})$ for $24 \mathrm{hrs}$. Media were collected and $\mathrm{NO}$ concentrations were determined by Griess Assay (B). Error bars represent the mean \pm SEM for three experiments. Values of $* p \leq 0.05$, $^{* *} p \leq 0.01$ and ${ }^{* * *} p \leq 0.001$ were considered statistically significant.

$N$. oleander has long been known for its toxic effects on oral use yet there are no toxicity or death report through the topical application or by corporal touch with the plant [49]. Consequently, there is only a limited number of utilization records in Turkish folk medicine mainly comprising external applications. The oily or alcohol extract of fresh flowers is applied to the aching joints against rheumatic pain or pounded flowers are directly wrapped externally on the affected extremities [45, $50]$.

A literature survey revealed that there are only a few reports regarding the anti-inflammatory activity of $N$. oleander. Anti-inflammatory activity of an Aloe vera-based extract of $N$. oleander leaves was investigated [35]. In another study, hydro-methanolic (70\%) extract of the leaves was also shown to exert immunomodulatory activity by up-regulating signal molecules, i.e. interleukin-2 (IL-2), IL-10, interferon-gamma and down regulating IL-4, tumor necrosis factor-alpha (TNF- $\alpha$ ), nitric oxide, cyclooxygenase- 1 (COX-1) and COX-2 and $\mathrm{PGE}_{2}[51,52]$. On the other hand, in our previous study, we investigated the anti-inflammatory and antinociceptive activities of fresh flowers. The EtOH extract was shown to exhibit potent in vivo antinociceptive activity as well as anti-inflammatory 
activity against carrageenan-induced hind paw edema model in mice without inducing any gastric damage [46]. The activity was found to be as potent as reference drug, indomethacin.

In the present study, we aimed to discover the activity mechanism of EtOH extract of fresh flowers and to determine the active constituents in its active EtOAc subextract. For this purpose, firstly NO inhibitory activity of the EtOH extract and its subextracts ( $n$-hexane, $\mathrm{CH}_{2} \mathrm{Cl}_{2}, \mathrm{EtOAc}, \mathrm{R}$ $\mathrm{H}_{2} \mathrm{O}$ ) were investigated. The crude EtOH extract did not significantly inhibit LPS induced NO production of Raw 264.7 macrophages, but $n$-hexane, $\mathrm{CH}_{2} \mathrm{Cl}_{2}$ and EtOAc subextracts provided significant inhibitions. This discrepancy might be due to the antagonistic effects of some of the components in the crude extract. Another explanation for this might be the elevation in relative concentrations of the active components in the subextract after partition. Hereby these results prompted us to focus on the EtOAc subextract which was the most active subextract without exerting toxicity towards Raw 264.7 macrophages.Despite exerting no inhibitory effect on COX-2 levels, a concentration dependent NO inhibitory activity of this extract was detected which is associated with the reduced levels of iNOS proteins. The subextract was also evaluated for its inhibitory effects on MAP kinases phosphorylation. However, the phosphorylation levels of MAP kinases were slighlty reduced by the treatment of this subextract. The highest effect was observed for ERK phosphorylation. Activity-guided fractionation of the EtOAc extract resulted in the isolation of one flavonol aglycone; kaempferol, one flavonol glycoside; kaempferol-3-O- $\beta$-glucopyranoside and one quinic acid derivative; chlorogenic acid. All of the compounds significantly inhibited NO productions in a concentration dependent manner.

The in vivo and in vitro anti-inflammatory activites of these three compounds were previously reported in several studies [53-56]. Chlorogenic acid was shown to decrease the levels of COX-2 and $\mathrm{PGE}_{2}$ and was also found to inhibit JNK, but not p38 and ERK (p44/42) phosphorylations on LPS induced Raw 264.7 macrophages [57]. Besides chlorogenic acid was found to inhibit the mRNA expressions of COX-2 and iNOS, and also decreased the levels of pro-inflammatory (IL-1 $\beta$, TNF $\alpha$, IL6) cytokines [58]. Although it was reported that pretreatment of Raw 264.7 macrophage cells with chlorogenic acid up to $37.5 \mu \mathrm{g} / \mathrm{mL}$ concentration did not significantly affect iNOS and NO levels when the cells were treated with LPS for 10 to 12 hours, another study revealed that significant inhibitory effect is attainable at relatively lower concentrations such as $20 \mu \mathrm{M}$ when cells were treated for $24 \mathrm{hrs}[57,58]$. In the present study, CA exerted significant NO inhibitory activity at higher concentrations $(100 \mu \mathrm{g} / \mathrm{mL})$ without inducing notable toxicity to cells.

The NO inhibitory effects of kaempferol was also demonstrated on various in vitro models with cell lines such as Raw 264.7, J774 macrophages and Chang liver cells, while kaempferol-3-O- $\beta$ glucoside was shown to reduce LPS-induced production of NO in J774A.1 cells [59-61]. Moreover, kaempferol and kaempferol-3-O- $\beta$-glucoside have been shown to display significant inhibitory activities on various signaling molecules (TNF $\alpha, \mathrm{PGE}_{2}, \mathrm{COX}-2$, iNOS, NF- $\mathrm{kB}$ ) which are known to involve in inflammatory process [59-61]. Accordingly, these previously conducted bioactivity studies on these secondary metabolites are in line with the results obtained in the present study. The current findings will shed light on the chemical composition and bioactive components of the oleander flowers.

The results of the present study have clearly proved the traditional use of the oily or alcohol extracts of $N$. oleander flowers to treat inflammatory diseases. The EtOAc subextract obtained from the EtOH extract of the oleander flowers was found to exert significant in vitro anti-inflammatory activity. The active components in this subextract were determined to be kaempferol, kaempferol-3-O$\beta$-D-glucoside and chlorogenic acid. Although these compounds were previously reported to be the anti-inflammatory components from several other plant remedies, their existence in the oleander flowers was reported for the first time here which would also contribute to the chemical profiling of the flowers. Apart from the EtOAc subextract, the $n$-hexane and $\mathrm{CH}_{2} \mathrm{Cl}_{2}$ subextracts also deserve to be deeply investigated in order to discover potential bioactive components.

\section{Acknowledgments}

This research did not receive any specific grant from funding agencies in the public commercial, or not-for-profit sectors. 


\section{ORCID}

İrem Atay Balkan: 0000-0002-7921-8621

Ahmet C Goren: : 0000-0002-5470-130X

Hasan Kırmizibekmez: 0000-0002-6118-8225

Erdem Yeşilada: 0000-0002-1348-6033

\section{References}

[1] L.M. Coussens and Z. Werb, (2002). Inflammation and cancer, Nature 420, 860-867.

[2] M. Feldmann and R.N. Maini (2003). TNF defined as a therapeutic target for rheumatoid arthritis and other autoimmune diseases, Nat. Med. 9, 1245-1250.

[3] C. Gabay (2006). Interleukin-6 and chronic inflammation, Arthritis Res. Ther. 6, 1-6.

[4] R. Gautam and S.M. Jachak (2009). Recent developments in anti-inflammatory natural products, Med. Res. Rev. 29,767-820.

[5] R.A. Heller, M. Schena, A. Chai, D. Shalon, T. Bedilion, J. Gilmore, D.E. Woolley and R.W. Davis (1997). Discovery and analysis of inflammatory disease-related genes using cDNA microarrays, Proc. Natl. Acad. Sci. U. S. A. 94, 2150-2155.

[6] B. Kaminska (2005). MAPK signalling pathways as molecular targets for anti-inflammatory therapyfrom molecular mechanisms to therapeutic benefits, Biochim. Biophys. Acta. 1754, 253-62.

[7] A. Gibofsky (2012). Overview of epidemiology, pathophysiology, and diagnosis of rheumatoid arthritis, Am. J. Manag. Care. 18, S295-302.

[8] A.E. M'Koma (2013). Inflammatory bowel disease: An expanding global health problem, Clin. Med. Insights Gastroenterol. 6, 33-47.

[9] C. Reitz, C. Brayne and R. Mayeux (2011). Epidemiology of Alzheimer disease, Nat. Rev. Neurol. 7, 137-152.

[10] P.Subbarao, P.J. Mandhane and M.R. Sears (2009). Asthma: epidemiology, etiology and risk factors, Can. Med. Assoc. J. 181, E181-190.

[11] F. Kuralay and Z. Çavdar (2006). Enflamatuvar mediyatörlere toplu bakış, Genel Tıp Derg. 16, 143 152.

[12] A. Tincani, L.Andreoli, C. Bazzani, D. Bosiso and S. Sozzani (2007). Inflammatory molecules: A target for treatment of systemic autoimmune diseases, Autoimmun. Rev. 7, 1-7.

[13] E. Yesilada, O. Ustün, E. Sezik, Y. Takaishi, Y. Ono and G. Honda (1997). Inhibitory effects of Turkish folk remedies on inflammatory cytokines: Interleukin-1alpha, interleukin-1beta and tumor necrosis factor alpha, J. Ethnopharmacol. 58, 59-73.

[14] S.H. Tsai, S.Y. Lin-Shiau and J.K. Lin (1999). Suppression of nitric oxide synthase and the downregulation of the activation of NFאB in macrophages by resveratrol, Br. J. Pharmacol. 126, 673-680.

[15] Y.C. Chen, S.C. Shen, W.R. Lee, W.C. Hou, L.L. Yang and T.J.F. Lee (2001). Inhibition of nitric oxide synthase inhibitors and lipopolysaccharide induced inducible NOS and cyclooxygenase-2 gene expressions by rutin, quercetin, and quercetin pentaacetate in RAW 264.7 macrophages, J. Cell. Biochem. 82, 537-548.

[16] G.M. Cooper and E.R. Hausman (2008). The cell: A molecular approach. 5th Edition. ASM Press. Washington, D.C., U.S.A.

[17] J. Gupta and A.R. Nebreda (2015). Roles of p38 $\alpha$ mitogen-activated protein kinase in mouse models of inflammatory diseases and cancer, FEBS J. 282, 1841-1857.

[18] G.L. Johnson and R. Lapadat (2002). Mitogen-activated protein kinase pathways mediated by ERK, JNK, and p38 protein kinases, Science 298, 1911-1912.

[19] C.C. Chen and J.K. Wang (1999). p38 but Not p44/42 Mitogen activated protein kinase is required for nitric oxide synthase induction mediated by lipopolysaccharide in RAW 264.7 macrophages, Mol. Pharmacol. 55, 481-488.

[20] D. Hwang, B.C. Jang, G. Yu and M. Boudreau (1997). Expression of mitogen-inducible cyclooxygenase induced by lipopolysaccharide, Biochem. Pharmacol. 54, 87-96.

[21] H.G. Kim, D.H. Yoon, W.H. Lee, S.K. Han, B. Shrestha, C.H. Kim, M.H. Lim, W. Chang, S. Lim, S. Choi, W.O. Song, J.M. Sung, K.C. Hwang and T.W. Kim (2007). Phellinus linteus inhibits inflammatory mediators by suppressing redox based NF-kappaB and MAPKs activation in lipopolysaccharide induced RAW 264.7 macrophage, J. Ethnopharmacol. 114, 307-15.

[22] T. Baytop (1999). Treatment with Plants in Turkey, Past and Today [Türkiye'de Bitkilerle Tedavi Geçmişte ve Bugün]. 2. ed. Nobel Tıp Kitabevi, İstanbul (in Turkish).

[23] F. Abe and T. Yamauchi (1992). Cardenolide triosides of oleander leaves, Phytochemistry. 31, 24592463. 
[24] F. Abe and T. Yamauchi (1992). Pregnanes from oleander leaves, Phytochemistry 31, 2819-2820.

[25] S. Begum, R. Sultana and B.S. Siddiqui (1997). Triterpenoids from the leaves of Nerium oleander, Phytochemistry. 44, 329-332.

[26] S. Begum, B.S. Siddiqui, R. Sultana, A. Zia and A. Suria (1998). Bio-active cardenolides from the leaves of Nerium oleander, Phytochemistry 50, 435-438.

[27] L.J. Rashan, K. Franke, M.M. Khine, G. Kelter, H.H. Fiebig, J. Neumann and L.A. Wessjohann (2011). Characterization of the anticancer properties of monoglycosidic cardenolides isolated from Nerium oleander and Streptocaulon tomentosum, J. Ethnopharmacol. 134, 781-8.

[28] S. Siddiqui, F. Hafeez, S. Begum and B.S. Siddiqui (1986). Isolation and structure of two cardiac glycosides from the leaves of Nerium oleander, Phytochemistry 26, 237-241.

[29] A. Siddiqui, S. Begum, F. Hafeez and B.S. Siddiqui (1989). Two triterpenes from the leaves of Nerium oleander, Phytochemistry 28, 1187-1191.

[30] B.S. Siddiqui, S. Begum, S. Siddiqui and W. Lichter (1995). Two cytotoxic pentacyclic triterpenoids from Nerium oleander, Phytochemistry 39, 171-174.

[31] B.S. Siddiqui, N. Khatoon, S. Begum, A.D. Farooq, K.,Qamar, H.A. Bhatti and S.K. Ali (2012). Flavonoid and cardenolide glycosides and a pentacyclic triterpene from the leaves of Nerium oleander and evaluation of cytotoxicity, Phytochemistry 77, 238-244.

[32] T. Yamauchi, N. Takata and T. Mimura (1975). Cardiac glycosides of the leaves of Nerium odorum, Phytochemistry 14,1379-1382.

[33] T. Yamauchi, M. Takahashi and F. Abe, (1976). Cardiac glycosides of the root bark of Nerium odorum, Phytochemistry 15, 1275-1278.

[34] R. Hanada, F. Abe and T. Yamauchi (1992). Steroid glycosides from the roots of Nerium odorum, Phytochemistry 31, 3183-3187.

[35] K.F. Benson, R.A. Newman and G.S. Jensen (2015). Antioxidant, anti-inflammatory, anti-apoptotic, and skin regenerative properties of an Aloe vera-based extract of Nerium oleander leaves (nae-8(®)), Clin. Cosmet. Investig. Dermatol. 8, 239-48.

[36] M.M. Huq, A. Jabbar, M.A. Rashid and C.M. Hasan (1999). A novel antibacterial and cardiac steroid from the roots of Nerium oleander, Fitoterapia. 70, 5-9.

[37] A. Zia, B.S. Siddiqui, S. Begum, S. Siddiqui and A. Suria (1995). Studies on the constituents of the leaves of Nerium oleander on behavior pattern in mice, J. Ethnopharmacol. 49, 33-39.

[38] M.S. Yu, S.W. Lai, K.F. Lin, J.N. Fang, W.H.Yuen and R.C. Chang (2004). Characterization of polysaccharides from the flowers of Nerium indicum and their neuroprotective effects, Int. J. Mol. Med. 14, 917-924.

[39] M.S. Yu, A.Y.Y. Wong, K.F.So, J.N. Fang, W.H. Yuen and R.C.C. Chang (2007). New polysaccharide from Nerium indicum protects neurons via stress kinase signaling pathway, Brain Res., 1153, 221-230.

[40] K.G. Singhal and G.D. Gupta, (2012). Hepatoprotective and antioxidant activity of methanolic extract of flowers of Nerium oleander against $\mathrm{CCl}_{4}$ induced liver injury in rats, Asian Pac. J. Trop. Med. 5, 677-685.

[41] K.G. Singhal and G.D. Gupta (2012). Neuroprotective appraisal of methanolic extract of flowers of Nerium oleander in a non classical rat model of Alzheimer disease, The Nat. Prod. J. 2, 235-245.

[42] V. Gayathri, S. Ananthi, C. Chandronitha, G. Ramakrishnan, R. Lakshmisundaram and H.R. Vasanthi (2011). Cardioprotective effect of Nerium oleander flower against isoproterenol-induced myocardial oxidative stress in experimental rats, J. Cardiovasc. Pharmacol. Ther. 16, 96-104.

[43] M. Mohadjerani (2012). Antioxidant activity and total phenolic content of Nerium oleander L. grown in North of Iran, IJPR. 11,1121-1126.

[44] D.S. Mohale, A.S. Tripathi, A.V.Shrirao, A.G. Jawarkar and A.V. Chandewar (2016). Evaluation of antioxidant effect of Nerium indicum in anxious rats. Ind. J.Pharmacol. 48, 430-433.

[45] E. Yesilada, (2002). Biodiversity in Turkish folk medicine. Kluwer Academic/Plenum Publishers. London, U.K.

[46] N. Erdemoglu, E. Küpeli and E. Yesilada (2003). Anti-inflammatory and antinociceptive activity assessment of plants used as remedy in Turkish folk medicine, J. Ethnopharmacol. 89, 123-129.

[47] P.K. Agrawal (1989). Carbon-13NMR of Flavonoids. Elsevier Scientific Publishing Co. New York.

[48] I. Saracoğlu, Ü.S. Harput and I. Çalış (2002). Phenolic constituents from Phlomis lycia, Turk. J. Chem. 26, 133-142.

[49] C. Kiran and D.N. Prasad (2014). A review on: Nerium oleander Linn. (Kaner), Int. J. Pharmacogn. Phytochem. Res. 6, 593-597.

[50] Y. Güzel, M. Güzelşemme and M. Miski (2015). Ethnobotany of medicinal plants used in Antakya: A multicultural district in Hatay Province of Turkey, J. Ethnopharmacol. 174, 118-152.

[51] P. Dey and T.K. Chaudhuri (2015). Anti-inflammatory activity of Nerium indicum by inhibition of prostaglandin E2 in murine splenic lymphocytes, Ind. J. Pharmacol. 47, 447-50.

[52] P. Dey and T.K. Chaudhuri (2016). Immunomodulatory activity of Nerium indicum through inhibition of nitric oxide and cyclooxygenase activity and modulation of TH1/TH2 cytokine balance in murine splenic lymphocytes, Cytotechnology 68, 749-761.

[53] M.D.D Santos, M.C. Almeida, N.P. Lopes and G.E. de Souza (2006). Evaluation of the antiinflammatory, analgesic and antipyretic activities of the natural polyphenol chlorogenic acid, Biol. Pharm. Bull. 29, 2236-2240.

[54] L. Kong, C. Luo, X. Li, Y. Zhou and H. He (2013). The anti-inflammatory effect of kaempferol on early atherosclerosis in high cholesterol fed rabbits, Lipids Health Dis. 12, 115. 
[55] M.Y.A. Mahat, N.M. Kulkarni, S.L. Vishwakarma, F.R. Khan, B.S. Thippeswamy, V. Hebballi, A.A. Adhyapak, V.S. Benade, S.M. Ashfaque, S. Tubachi and B.M. Patil (2010). Modulation of the cyclooxygenase pathway via inhibition of nitric oxide production contributes to the anti-inflammatory activity of kaempferol, Eur. J. Pharmacol. 642, 169-176.

[56] Y. Wang, P. Chen, C. Tang, Y. Wang, Y. Li and H. Zhang (2014). Antinociceptive and anti-inflammatory activities of extract and two isolated flavonoids of Carthamus tinctorius L, J. Ethnopharmacol. 151, 944-950.

[57] J. Shan, J. Fu, Z. Zhao, X. Kong, H. Huang, L. Luo and Z. Yin (2009). Chlorogenic acid inhibits lipopolysaccharide induced cyclooxygenase-2 expression in RAW264.7 cells through suppressing NF$\kappa \mathrm{B}$ and JNK/AP-1 activation, Int. Immunopharmacol. 9, 1042-1048.

[58] S.J. Hwang, Y.W. Kim, Y. Park, H.J. Lee and K.W. Kim (2014). Anti-inflammatory effects of chlorogenic acid in lipopolysaccharide-stimulated RAW 264.7 cells, Inflamm. Res. 63, 81-90.

[59] M. Hamalainen, R. Nieminen, P. Vuorela, M. Heinonen and E. Moilanen (2007). Anti-inflammatory effects of flavonoids: genistein, kaempferol, quercetin, and daidzein inhibit stat-1 and NF- $\kappa \mathrm{B}$ activations, whereas flavone, isorhamnetin, naringenin, and pelargonidin inhibit only NF- $\mathrm{B}$ activation along with their mhibitory effect on iNOS expression and NO production in activated macrophages, Mediators Inflamm. 45673, doi: 10.1155/2007/45673.

[60] M.S. Kim and S.H. Kim (2011). Inhibitory effect of astragalin on expression of lipopolysaccharideinduced inflammatory mediators through NF- $\kappa \mathrm{B}$ in macrophages, Arch. Pharm. Res. 34, 2101-2107.

[61] N.X. Nhiem, B.H. Tai, T.H. Quang, P.V. Kiem, C.V. Minh, N.H. Nam, J.H. Kim, L.R. Im, Y.M. Lee and Y.H. Kim (2011). A new ursane-type triterpenoid glycoside from Centella asiatica leaves modulates the production of nitric oxide and secretion of TNFa in activated RAW 264.7 cells, Bioorg. Med. Chem. Lett. 21, 1777-1781.

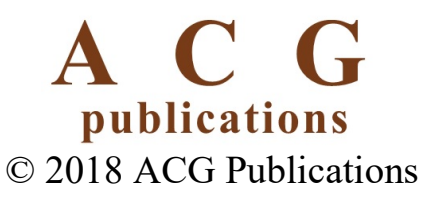

